\title{
Burnout Levels and Personality Traits-The Case of Turkish Architectural Students
}

\author{
Gözde Tantekin Celik ${ }^{1 *}$, Emel Laptali Oral ${ }^{2}$ \\ ${ }^{1}$ Architectural Department, Engineering and Architectural Faculty, Çukurova University, Adana, Turkey \\ ${ }^{2}$ Civil Engineering Department, Engineering and Architectural Faculty, Çukurova University, Adana, Turkey \\ Email: "gtantekin@cu.edu.tr
}

Received December $3^{\text {rd }}, 2012$; revised January $7^{\text {th }}, 2013$; accepted January $19^{\text {st }}, 2013$

\begin{abstract}
The aim of this research has been to investigate the relationship between personality traits and burnout levels of architectural undergraduate students. Maslach Burnout Inventory-Student Survey (MBI) and Five Factor Model were used to collect related data. Analysis of the collected data showed variations in personality traits and burnout levels of students from first to fourth year and revealed that education process was an important role player in personality development and burnout levels of students. Architectural students tended to be more "open to experience" and "extraverted" as they proceeded from the first year to final year without having high levels of "emotional exhaustion". "Emotional exhaustion" was observed together with "neurotic" personality traits of students. Thus, one of the key recommendations of this research is that university counselors should plan and organize guidance programmes by focusing on individual requirements caused by both the student's personality traits and demands of the university education which may vary between both years and departments. Future work of this research will thus focus on civil engineering and computer engineering students in order to determine the effect of departmental differences on burnout levels of students and guide counseling programmes within the University accordingly.
\end{abstract}

Keywords: Architectural Students' Burnout; Five Factor Model; Maslach Burnout Inventory-Student Survey; Personality

\section{Introduction}

Students' burnout is one of the important areas of investigation in higher education as it may the key for understanding a wide range of students' behaviours that affect academic performance. In parallel, previous studies have determined personality as one of the key factors that affect burnout levels of different professional groups. These studies have focused on determining the relationship between personality and burnout by using Maslach Burnout Inventory (MBI) and Five Factor Model. However, limited number of studies on university students and none on architectural students have been undertaken. Thus, the aim of the current research has been to determine both the burnout levels and the personality traits of architectural students and the relationship between these two factors.

\section{Personality, Personality Traits and Five Factor Model}

The term "Personality" has been defined in many ways since 1930s when the systematic study of personality started to be a recognizable and a separate discipline

(http://www.britannica.com/). It is commonly defined as the integration of physiologic, intellectual and mental characteristics that makes an individual different from other individuals (Dubrin, 1994; Davies, 1998; Morgan, 1999; Güney, 2000; Costa, 2000; Eysenck \& Wilson, 2000; Eren, 2000). In other words, "Personality" is defined as the combination and interac-

\footnotetext{
*Corresponding author.
}

tion of various traits that is unique to each individual. Various trait theories, thus, have been developed in order to identify (theories of Freud, Adler, Horney, Fromm and Jung (Deniz, 2007)) and also to measure (theories of Adler, Horney, Fromm, Jung, Cattel, Fiske, Eysenck, Norman (Deniz, 2007)) these traits.

The "Five Factor Theory" or the so called "Big Five", has been one of the most widely used trait measurement theories. It has been used by various researchers like Goldberg (1990); Somer and Goldberg, (1999); Chernyshenko (2001); Kokkonen and Pulkkinen (2001); Somer et al. (2002); Storm and Rothmann (2003); Bühler and Land (2004); Tomic et al. (2004); Tichon (2005); Bakker et al. (2006); Demirkan (2006); Şimşek (2006); Kokkinos (2007); Morgan (2008); Kim et al. (2009); Lent (2010); Swider and Zimmerman (2010) and Zopiatis et al. (2010) for different groups of individuals and professionals. The theory was developed by Norman (1963). Working on Allport and Odbert (1936)'s Factor Theory, Norman (1963) declared that five major factors; i.e. dimensions were sufficient to account for a large set of personality data. The model has been preferred by many researchers, since then, due to its ability in responding the modelling requirements of personality traits of different individuals from all age groups in a short period of time. The following paragraphs summarise the relationship between "Five Factor Dimensions" and related behaviors.

\section{Extraversion-Introversion}

This dimension is described as "the interest to the outer world" and includes some features like friendliness, loving 
people, being assertive, excitement seeking, being energetic, and thinking positive (Demirkan, 2006). Extraverted individuals are optimistic, enthusiastic, full of energy and they love being together with people. They react to situations without thinking, and they are likely to say "yes" to the opportunities. (McCrae, Costa, 2000; Loveland, 2004). Introverts, on the other hand, lack enthusiasm, energy and mobility tendencies of extraverts. But, their lack of social involvement is not related with shyness or depression. They simply have less stimulation than extraverts and they choose to have more time alone.

\section{Agreeableness_-Offensiveness}

This dimension of personality reflects individual differences related to collaboration and social compliance. Agreeable individuals are respectful, friendly, helpful, generous and get along with others easily as they have an optimistic view of human nature. They believe people are basically honest, decent, and trustworthy. Meanwhile, offensive individuals place self-interest above getting along with others. They are generally unconcerned with others' well-being. Sometimes their scepticism causes them to be suspicious, unfriendly, and uncooperative (Martinez, Thomas, 2005; Friday, 2004).

\section{Conscientiousness-Aimlessness}

Conscientiousness is about controlling, organizing and managing one's instincts. It includes some personality traits like being analytical, responsible, prudent, patient and working hard. Conscientious individuals are attributed as intelligent and reliable. The downside, on the other hand, is that these individuals can sometimes be perfectionist, workaholic, conservative and boring. Contrarily, individuals with low conscientiousness are criticized about not being reliable, enthusiastic and consistent (Perry, 2003).

\section{Neuroticism-Emotional Stability}

This dimension of personality includes features like anxiety, anger, hatred, depression, inconsideration and thoughtlessness. People who are emotionally tend to be calm, free from persistent negative feelings and are not easily upset (Martinez \& Thomas, 2005; Cook, 2005). Neurotic individuals, on the other hand, experience at least one of the feelings like concern, anger or depression very easily. These individuals generally have tendency to worry, to be sad, to feel lonely and dejected. However, they don't feel shy even with strangers (Costa \& McCrae, 2000).

\section{Openness to Experience-Conservatism}

This dimension expresses an individual's tendency to be open to different beliefs, view points and experiences (Aghaee \& Ören, 2004). Individuals who are open to experience are intellectually curious, appreciative of art, and sensitive to beauty (Turner, 2003). They tend to be more aware of their feelings. Conservative people who are not open to innovations, are against changes, and they perceive art and science with suspicion and they prefer traditional to contemporary (Ehrler, 2005).

\section{Limitations of Five Factor Model}

While the model has been used for determining the personal- ity traits of different groups by various number of researchers as listed in the previous section, it has also been criticised by some researchers related with the its limitations in reflecting the differences caused by factors like gender and culture (Costa et al. (2001), McRae et al. (2005), Schmitt et al. (2008), Cheung et al. (2011)).

\section{Burnout}

"Burnout" is a psychological term for the experience of long-term exhaustion and diminished interest (http://en. wikipedia.org/wiki/Burnout_(psychology)). "Burnout" syndrome has not been studied extensively until 1970s and early studies on the subject prevailed conceptual confusion (Schaufeli \& Enzmann, 1998). However, Maslach and Jackson's measurement method that is, Maslach Burnout Inventory (MBI), ended the foregoing confusion and has been the most well-studied measurement of burnout (Maslach et al., 1996). Storm \& Rothmann, 2003; Bühler \& Land 2004; Tomic et al., 2004; Bakker et al., 2006; Kokkinos, 2007; Ghorpade et al., 2007; Kim et al., 2009; Lent, 2010; Swider \& Zimmerman, 2010; Zopiatis et al., 2010 have been some of the recent researchers who used MBI to measure the burnout levels of different individuals and professionals. MBI measures burnout level of individuals according to three dimensions. These are "emotional exhaustion", "cynicism" and "reduced personal accomplishment".

\section{Emotional Exhaustion}

Emotional exhaustion refers to chronic state of physical and emotional depletion (http://en.wikipedia.org/). The major sources of emotional exhaustion are work overload and personal conflict at work. People feel drained and used up without any source of replenishment. They lack enough motivation to face another day or another person in need. This component represents the basic stress dimension of burnout (Maslach \& Goldberg, 1998; Jackson \& Rothmann, 2005).

\section{Cynicism (Depersonalization)}

Cynicism (Depersonalization) refers to a negative, cruel or excessively detached response to other people, and it often includes a loss of idealism. It usually develops in response to the overload of emotional exhaustion in form of a self-protection by putting an emotional buffer with other individuals. This component represents the interpersonal dimension of burnout (Maslach \& Goldberg, 1998; Pienarr \& Wyk, 2006).

\section{Personal Accomplishment}

Personal accomplishment reflects feelings of competence (Maslach et al., 1996). Reduced personal accomplishment refers to a decline in one's self competence and productivity at work. A growing sense of inadequacy is experienced about one's own personal ability to help people, and this may result in a selfimposed verdict of failure. This component represents the selfevaluation dimension of burnout (Maslach \& Goldberg, 1998).

\section{Students’ Academic Burnout}

In legal sense, students are not formal workers but, from a psychological point of view, most of student activities related 
to their studies are comparable to formal work. Students have specified roles and they perform activities that require effort, just like formal workers. They have to attend regular activities (classes) and undertake specific tasks under the control of their supervisors, and their performances are regularly assessed. The main difference of study settings from formal work settings is the lack of a direct relationship with the money. But, in one sense, there is an indirect relationship between student activities and money as most of the students obtain grants or financial support depending on their academic achievements (Esteve, 2003).

Students' burnout can be noticeable in several ways like; feeling exhausted because of academic demands, having a cynical and detached attitude towards their studies, and feeling incompetent as a student (Lee et al., 2010). Thus, a student version of Maslach Burnout Inventory, i.e. Maslach Burnout Inventory-Student Survey (MBI-SS), was developed by Schaufeli et al. (2002) in order to measure students' burnout.
MBI-SS provides norm-referenced measures of students' academic burnout syndrome through exhaustion, cynicism, academic efficacy and academic inefficacy. It has been used by various researchers like Esteve (2003), Lingard et al. (2007), Gan ve Shang (2007), Breso et al. (2007), Zhang et al. (2007), Jia et al. (2009a), Salanova et al. (2009), Jia et al. (2009b), Hu ve Schaufeli (2009), Lee et al. (2010), Breso et al. (2011). Meanwhile, among all of these researchers, only Jia et al. (2009) studied burnout levels of architecture students and observed "low" burnout levels for both emotional exhaustion and academic efficacy and "very low" burnout levels for cynicism.

\section{Previous Research Findings on Relationship between Personality Traits and Burnout Levels}

Table 1 shows previous research results on the relationship between personality traits and burnout levels and these results are discussed in the following paragraphs considering the fact

Table 1.

Relationship between personality traits and burnout levels.

\begin{tabular}{|c|c|c|c|c|c|c|c|}
\hline & & & \multicolumn{5}{|c|}{ Five factor personality traits } \\
\hline & & & Extraversion & Neuroticism & Conscientiousness & Agreeableness & $\begin{array}{c}\text { Openness } \\
\text { to experience }\end{array}$ \\
\hline Research No & Research & Burnout sub-dimensions & & & Correlation coefficie & & \\
\hline \multirow{3}{*}{1} & \multirow{3}{*}{$\begin{array}{l}\text { Storm and Rothmann } \\
\text { (2003) on pharmaceutical } \\
\text { corporate employees }\end{array}$} & Emotional exhaustion & -0.310 & 0.210 & -0.210 & -0.190 & -0.060 \\
\hline & & Cynicism & -0.260 & 0.210 & -0.130 & -0.230 & -0.030 \\
\hline & & Personal accomplishment & 0.270 & -0.210 & 0.210 & 0.090 & 0.340 \\
\hline \multirow{3}{*}{2} & \multirow{3}{*}{$\begin{array}{l}\text { Tomic et al. (2004) } \\
\text { on church ministers }\end{array}$} & Emotional exhaustion & -0.414 & 0.640 & - & - & - \\
\hline & & Cynicism & -0.314 & 0.359 & - & - & - \\
\hline & & Personal accomplishment & -0.463 & -0.496 & - & - & - \\
\hline \multirow{3}{*}{3} & \multirow{3}{*}{$\begin{array}{l}\text { Bakker et al. ( } 2006) \\
\text { on volunteer counselors }\end{array}$} & Emotional exhaustion & -0.010 & 0.360 & 0.100 & -0.050 & -0.080 \\
\hline & & Cynicism & -0.200 & 0.260 & 0.080 & -0.150 & -0.230 \\
\hline & & Personal accomplishment & 0.350 & -0.170 & -0.010 & 0.250 & 0.170 \\
\hline \multirow{3}{*}{4} & \multirow{3}{*}{$\begin{array}{l}\text { Kokkinos (2007) on } \\
\text { school teachers }\end{array}$} & Emotional exhaustion & -0.230 & 0.500 & 0.360 & - & 0.060 \\
\hline & & Cynicism & -0.220 & 0.290 & 0.180 & - & -0.160 \\
\hline & & Personal accomplishment & 0.330 & -0.260 & -0.150 & - & 0.150 \\
\hline \multirow{3}{*}{5} & \multirow{3}{*}{$\begin{array}{l}\text { Ghorpade et al. (2007) } \\
\text { on university instructors }\end{array}$} & Emotional exhaustion & -0.213 & 0.338 & -0.101 & -0.135 & 0.015 \\
\hline & & Cynicism & -0.800 & 0.354 & -0.164 & -0.438 & -0.770 \\
\hline & & Personal accomplishment & 0.221 & -0.321 & 0.307 & 0.356 & 0.251 \\
\hline \multirow{3}{*}{6} & \multirow{3}{*}{$\begin{array}{l}\text { Morgan (2008) on } \\
\text { university students }\end{array}$} & Emotional exhaustion & -0.129 & 0.343 & -0.167 & -0.077 & -0.096 \\
\hline & & Cynicism & -0.139 & 0.266 & -0.229 & -0.174 & -0.060 \\
\hline & & Academic efficacy & 0.211 & -0.245 & 0.444 & 0.226 & 0.250 \\
\hline \multirow{3}{*}{7} & \multirow{3}{*}{$\begin{array}{l}\text { Kim et al. (2009) on } \\
\text { quick service restaurants } \\
\text { employees }\end{array}$} & Emotional exhaustion & -0.120 & 0.400 & -0.130 & -0.100 & -0.090 \\
\hline & & Cynicism & 0.210 & 0.380 & -0.240 & -0.280 & -0.070 \\
\hline & & Personal accomplishment & 0.100 & -0.170 & 0.410 & 0.260 & 0.110 \\
\hline \multirow{3}{*}{8} & \multirow{3}{*}{$\begin{array}{l}\text { Lent }(2010) \text { on } \\
\text { professional counselors }\end{array}$} & Emotional exhaustion & 0.215 & 0.642 & 0.349 & 0.281 & 0.056 \\
\hline & & Cynicism & 0.142 & 0.388 & 0.234 & 0.373 & 0.025 \\
\hline & & Personal accomplishment & 0.196 & 0.430 & 0.288 & 0.350 & 0.405 \\
\hline \multirow{3}{*}{9} & \multirow{3}{*}{$\begin{array}{l}\text { Swider and Zimmerman } \\
\text { (2010) on various } \\
\text { individuals }\end{array}$} & Emotional exhaustion & -0.290 & 0.520 & -0.190 & -0.180 & -0.090 \\
\hline & & Cynicism & -0.230 & 0.420 & -0.240 & -0.310 & -0.100 \\
\hline & & Personal accomplishment & 0.410 & -0.380 & 0.280 & 0.310 & 0.210 \\
\hline \multirow{3}{*}{10} & \multirow{3}{*}{$\begin{array}{l}\text { Zopiatis et al. (2010) } \\
\text { on hotel managers }\end{array}$} & Emotional exhaustion & -0.396 & 0.493 & -0.385 & -0.234 & -0.218 \\
\hline & & Cynicism & -0.409 & 0.365 & -0.437 & -0.527 & -0.113 \\
\hline & & Personal accomplishment & 0.305 & -0.208 & 0.337 & 0.160 & 0.211 \\
\hline
\end{tabular}


that relationship between variables are weak for $0.1-0.23$, medium for $0.24-0.36$, and strong for 0.37 and over correlation coefficient values (Cohen et al., 2002).

In Table 1, results show that although some are weakly correlated, there is generally a negative correlation between "extraversion" and both "emotional exhaustion" and "cynicism", and there is a positive correlation between "extraversion" and "personal accomplishment". These results are in good agreement with the positive correlation values between "neuroticcism" and both "emotional exhaustion" and "cynicism" and negative correlation values between "neuroticism" and "personal accomplishment". Thus, it can be underlined that while "emotional exhaustion" and "cynicism" go together with "neuroticism" but happen to be in opposite directions with "extraversion", "personal accomplishment" behaves parallel with "extraversion". Positive correlation of "personal accomplishment/academic efficacy" with both "conscientiousness" and "agreeableness" additionally show that it is not only "extraversion" but also "conscientiousness" and "agreeableness" which are in parallel direction with "personal accomplishment" for most of the professionals studied.

\section{Research Methodology}

Big Five Inventory (BFI) (John \& Srivastava, 1999) and Maslach Burnout Inventory-Student Survey (MBI-SS) (Schaufeli et al., 2002) questionnaires were used together in order to achieve the objectives of the current research. Questionnaires were first translated to Turkish and then applied to 208 architectural students in Çukurova University in Turkey. Students were asked to respond to questionnaire items by using the 5-point Likert scale that ranged from "disagree strongly" to "agree strongly". For BFI, high Likert scale scores were the indicators of extraversion, agreeableness, conscientiousness, neuroticism and openness to experience. For MBI-SS, responses were interpreted according to the criterion given in Table 2 (Gökdaş, 1996; Tekin, 1996). High Likert scale scores on emotional exhaustion, cynicism and academic inefficacy, and low scale scores on academic efficacy were considered as the indicators of burnout (Breso et al., 2007).

The relationship between academic burnout and personality traits were additionally investigated by undertaking correlation calculations. Statistical analysis was evaluated by using "Microsoft Office Excel 2007 for Windows" and "SPSS 17.0 for Windows" software programs. The strength of the correlation coefficients are interpreted as in previous section.

\section{Research Findings and Discussion}

\section{Reliability of Scales}

Cronbach Alpha Coefficient (CAC) was used to determine the reliability of the questionnaires (Myburgh et al., 2011). The minimum CAC value being over 0.6 (see Table 3 ) shows that the Turkish interpretation of the questionnaires are fairly reliable.

\section{Profile and Demographic Characteristics of the Respondents}

Profile and demographic characteristics of the respondents are given in Table 4 .
Table 2.

The sub-dimension rating criterion of MBI-SS.

\begin{tabular}{cccc}
\hline Score & $\begin{array}{c}\text { Lower - } \\
\text { upper limit }\end{array}$ & $\begin{array}{c}\text { Emotional } \\
\text { exhaustion/cynicism/academic } \\
\text { inefficacy }\end{array}$ & $\begin{array}{c}\text { Academic } \\
\text { efficacy }\end{array}$ \\
\hline 1.00 & $1.00-1.79$ & Very low burnout & Very high burnout \\
2.00 & $1.80-2.59$ & $\begin{array}{c}\text { Low burnout } \\
\text { Medium/moderate } \\
\text { burnout }\end{array}$ & $\begin{array}{c}\text { High burnout } \\
\text { Medium/moderate } \\
\text { burnout }\end{array}$ \\
3.00 & $2.60-3.39$ & High burnout & Low burnout \\
4.00 & $3.40-4.19$ & Very high burnout & Very low burnout \\
5.00 & $4.20-5.00$ & & \\
\hline
\end{tabular}

Table 3.

Cronbach alfa coefficient values of the questionnaire sections.

\begin{tabular}{ll}
\hline \multicolumn{2}{c}{ Scale cronbach alfa coefficient } \\
\hline Personality (as a whole) & 0.761 \\
Extraversion & 0.734 \\
Agreeableness & 0.601 \\
Conscientiousness & 0.628 \\
Emotional stability & 0.611 \\
Openness to experience & 0.798 \\
Burnout (as a whole) & 0.718 \\
Emotional exhaustion & 0.835 \\
Cynicism & 0.729 \\
Academic efficacy & 0.717 \\
Academic inefficacy & 0.671 \\
\hline
\end{tabular}

Table 4.

Profile of the respondents.

\begin{tabular}{ccccc}
\hline \multirow{2}{*}{ Grade } & \multirow{2}{*}{$\begin{array}{c}\text { Number of } \\
\text { respondents }\end{array}$} & $\begin{array}{c}\text { \% of } \\
\text { respondents }\end{array}$ & \multicolumn{2}{c}{$\begin{array}{c}\text { Gender of respondents } \\
(\%)\end{array}$} \\
\cline { 4 - 5 } First year & 48 & 23 & 6 & Male \\
Second year & 44 & 21 & 7 & Female \\
Third year & 24 & 12 & 2 & 14 \\
Fourth year & 92 & 44 & 19 & 25 \\
Total & 208 & 100 & 34 & 66 \\
\hline
\end{tabular}

\section{Burnout Levels of Architectural Students}

The questionnaire findings related with the burnout levels of architectural students are given in Table 5 . The mean value $(\overline{\mathrm{X}})$ being 2.59 for "emotional exhaustion" indicates "low level" of burnout at this sub-dimension and the coefficient of variation $\left(\mathrm{V}^{-}\right)$being smaller than 0.5 shows the homogeneity of the students' answers. This result indicates that the education and academic atmosphere in Architectural Department in Çukurova University doesn't cause students an unnecessary stress. Meanwhile, the "medium level" emotional exhaustion results for first and third year students may be due to the characteristics of these two classes. These are the years of transition during which first year students try to adapt to university life and architectural thinking and third year students undertake three important projects ("Architectural Project", "City Planning 
Project" and "Conservation and Restoration Project") simultaneously. Inevitable, these two years require a more intense working tempo.

Low cynicism and academic inefficacy together with high academic efficacy results in Table V show that students are able to cope with the academic demands of their department and feel adequate and competent. The project based education system in the department requires students to be the part of the process and is an important motivation for the students which results in emotional attachment between the students and their work.

When students' expectations on their architectural design lesson grades are compared with their actual grades, it is observed that the expected grades are much higher than the actual grades (Table 6). 77 per cent of the students didn't get marks as high as they expected which shows that the students are too optimistic about their "academic efficacy".

\section{Relationship between the Sub-Dimensions of Burnout}

Inter item correlation values for burnout sub-dimensions for architectural students are given in Table 7. Results which are in good agreement with the previous studies like Schaufeli et al. (2002), Tomic (2004), Breso et al. (2007), Gan et al. (2007), Ghorpade et al. (2007), Kokkinos (2007), Lingard et al. (2007), Zhang et al. (2007), Morgan, (2008); Hu and Schaufeli (2009), Kim et al. (2009), Salanova et al. (2009), Swider and Zimmerman (2010), Zopiatis (2010), show that "emotional exhaustion", "cynicism" and "academic inefficacy" are strongly correlated with each other. Additionally, "academic efficacy", is negatively correlated with "cynicism" and "academic inefficacy": These findings are parallel to the findings of Breso et al. (2007) which prove that while there is a significant positive correlation between "academic inefficacy" and "cynicism" of university

Table 5.

Burnout levels of architectural students.

\begin{tabular}{ccccc}
\hline & $\begin{array}{c}\text { Emotional } \\
\text { Exhaustion }\end{array}$ & Cynicism & $\begin{array}{c}\text { Academic } \\
\text { Efficacy }\end{array}$ & $\begin{array}{c}\text { Academic } \\
\text { Inefficacy }\end{array}$ \\
\hline 1st year & 2.68 & 2.24 & 3.38 & 2.09 \\
2nd year & 2.56 & 2.05 & 2.55 & 2.31 \\
3rd year & 2.99 & 2.55 & 23.63 & 2.06 \\
4th year & 2.46 & 2.31 & 3.76 & 1.99 \\
$\overline{\mathrm{X}}$ & 2.59 & 2.26 & 3.64 & 1.98 \\
$\sigma$ & 1.03 & 0.92 & 0.74 & 0.73 \\
${ }^{-} \mathrm{V}^{-}$ & 0.40 & 0.41 & 0.20 & 0.37 \\
\hline
\end{tabular}

Table 6.

"Architectural design" lesson grades.

\begin{tabular}{|c|c|c|c|}
\hline \multirow[b]{2}{*}{ Grade } & \multicolumn{3}{|c|}{$\%$ of Respondents } \\
\hline & $\begin{array}{l}\text { Expectation } \\
\text { higher than } \\
\text { the achievement }\end{array}$ & $\begin{array}{l}\text { Expectation the } \\
\text { same with the } \\
\text { achievement }\end{array}$ & $\begin{array}{l}\text { Expectation } \\
\text { lower than the } \\
\text { achievement }\end{array}$ \\
\hline 1st grade & 69 & 23 & 9 \\
\hline 2nd grade & 76 & 13 & 11 \\
\hline 3rd grade & 75 & 20 & 5 \\
\hline 4 th grade & 81 & 11 & 8 \\
\hline Total & 76 & 15 & 8 \\
\hline
\end{tabular}

Table 7.

Inter-item correlation between burnout sub-dimensions.

\begin{tabular}{lcccc}
\hline Variables & 1 & 2 & 3 & 4 \\
\hline 1) Emotional Exhaustion & 1 & & & \\
2) Cynicism & $0.659^{* *}$ & 1 & & \\
3) Academic Efficacy & $-0.195^{* *}$ & $-0.284^{* *}$ & 1 & \\
4) Academic Inefficacy & $0.554^{* *}$ & $0.621^{* *}$ & $-0.408^{* *}$ & 1 \\
\hline
\end{tabular}

Note: ${ }^{* *}$ Indicates $p<0.01$ (2-tailed).

students, there is a negative correlation between "academic inefficacy" and "academic efficacy". Findings of Breso et al. (2007) also show that both "emotional exhaustion" and "cynicism" have higher correlation with "academic inefficacy" than with "academic efficacy".

\section{Personality Traits of Architectural Students}

Five Factor Personality scores of architectural students according to the BFI data are given in Table 8. First year students' scores show that "agreeableness", "openness to experience" and "conscientiousness" are more dominant personality traits of these students. When the results of first and final year students are compared, it is observed that the education process has an effect on personality traits of students. Results show that, after four years in architectural department, students become more "extraverted" and more "open to experience". This is probably due to the fact that project based education enables the students' communication skills to develop, as they have to communicate with different types of people related with their project subject and have to carry out regular presentations to their classmates and lecturers. The intense communication requirements of this process enhance the extravert traits of the students. Additionally, the requirements of architectural design process to follow the new technologies and developments also enhance the extravert traits of students. Strong correlation between "extraversion" and "openness to experience" (similar to the findings of Morgan (2008), Swider and Zimmerman (2010) and Zopiatis (2010)) additionally show that these two traits support each other during personality development of students (see Table 9). Meanwhile, "neuroticism" dimension scores res show that students have a moderate emotional stability during their educational process. The results in Table 8 finally show that architectural education has no significant effect on "conscientious" and "agreeableness" personality traits. This finding is also supported by the positive correlation values between these two personality traits (see Table 9).

\section{Relationship between Burnout Levels and Personality Traits of Architectural Students}

Results in Table 10 show the correlation coefficient values between "Burnout" and "Five Factor Personality Traits" sub dimensions.

Results show that the strongest correlations are between "academic efficacy" and "conscientiousness" (0.534), "emotional exhaustion" and "neuroticism" (0.406) and "academic efficacy" and "extraversion" (0.346). These results are in good agreement with the results of both Ghorpade et al. (2007), Kim et al. (2009), Zopiatis et al. (2010) who investigated correlation between "professional efficacy" and "conscientiousness" for 
Table 8.

Five factor personality trait scores of architectural students.

\begin{tabular}{cccccc}
\hline & Extraversion & Neuroticism & Openness to experience & Agreeableness & Conscientiousness \\
\hline 1st year & 3.13 & 3.14 & 3.89 & 3.94 & 3.65 \\
2nd year & 3.46 & 2.94 & 3.88 & 3.92 & 3.69 \\
3rd year & 3.37 & 3.07 & 3.69 & 3.82 & 3.53 \\
4th year & 3.52 & 2.89 & 4.03 & 3.94 & 3.70 \\
$\overline{\mathrm{X}}$ & 3.40 & 2.97 & 3.92 & 3.92 & 3.67 \\
$\sigma$ & 0.72 & 0.73 & 0.75 & 0.53 & 0.64 \\
$-\mathrm{V}^{-}$ & 0.21 & 0.25 & 0.19 & 0.14 & 0.17 \\
\hline
\end{tabular}

Table 9.

Correlation coefficient values between five factor personality dimensions.

\begin{tabular}{|c|c|c|c|c|c|}
\hline Variables & 1 & 2 & 3 & 4 & 5 \\
\hline 1) Extraversion & 1 & & & & \\
\hline 2) Neuroticism & $-0.243^{* *}$ & 1 & & & \\
\hline 3) Openness to experience & $0.395^{* *}$ & -0.040 & 1 & & \\
\hline 4) Agreeableness & $0.159^{*}$ & 0.107 & $0.255^{* *}$ & 1 & \\
\hline 5) Conscientiousness & $0.173^{*}$ & $-0.250^{* *}$ & $0.218^{* *}$ & $0.225^{* *}$ & 1 \\
\hline
\end{tabular}

Note: ${ }^{*}$ Indicates $p<0.05,{ }^{* *}$ Indicates $p<0.01$ (2-tailed).

Table 10.

Correlation coefficient values between burnout sub dimensions and five factor personality sub dimensions.

\begin{tabular}{lccccc}
\hline \multicolumn{1}{c}{ Variables } & Extraversion & Neuroticism & Open to experience & Agreeableness & Conscientiousness \\
\hline 1) Emotional exhaustion & -0.166 & 0.406 & -0.174 & -0.071 & -0.251 \\
2) Cynicism & -0.118 & 0.255 & -0.180 & -0.143 & -0.324 \\
3) Academic efficacy & 0.346 & -0.207 & 0.298 & 0.206 & 0.534 \\
4) Academic inefficacy & -0.226 & 0.207 & -0.304 & -0.158 & -0.429 \\
\hline
\end{tabular}

various professional groups and Bakker et al. (2006), Kokkinos (2007), Morgan (2008), Kim et al. (2009), Swider and Zimmerman (2010), Lent (2010), Zopiatis et al. (2010), Tomic et al. (2004), Ghorpade et al. (2007) who established positive correlation between "emotional exhaustion" and "neuroticism".

The results in Table $\mathbf{1 0}$ additionally show that while "conscientiousness" and "extraversion" are two important characteristics that come together with "academic efficacy", neurotic personality traits go together with "emotional exhaustion" and "academic inefficacy". These results are also in good agreement with the results of Bakker et al. (2006), Kokkinos (2007), Swider and Zimmerman (2010), Zopiatis et al. (2010) on professional efficacy. Additionally, the negative correlation result between architectural students" "cynicism" with "conscientiousness" is also supported by the findings of Storm and Rothmann (2003), Ghorpade et al. (2007), Morgan (2008), Kim et al. (2009), Swider and Zimmerman (2010) and Zopiatis's et al. (2010).

\section{Conclusion}

Literature shows that personality is one of the key factors that affect burnout levels of different professional groups. Little research has been undertaken related with architectural students. Thus, the aim of the current research has been to determine both the burnout levels and the personality traits of architectural students and the relationship between these two factors. Maslach Burnout Inventory-Student Survey and Five Factor Model were used in order to achieve this. Turkish interpretation of both of the surveys is verified to be fairly reliable and can be used to determine the burnout levels and personality traits of Turkish students.

Findings of the current research show that architectural students have low burnout levels in general, and levels of "emotional exhaustion", "cynicism" and "academic inefficacy" are all strongly related with each other. While it is undeniable that "emotional exhaustion" levels of students increase under stress, "neurotic" personality is also an important trait that is related with "emotional exhaustion". Other two key personality traits related with burnout levels are "conscientiousness" and "extraversion", which are strongly related with "academic efficacy".

Comparison of personality traits between four academic years gives evidence that while architectural education process does not have any significant effect on "conscientiousness" and "agreeableness" personality traits of students; it has a positive effect on not only "openness to experience" and "extraversion" traits, but also on "neuroticism".

It can be concluded from these findings that while the nature of the architectural education inevitably directs the personality 
of students towards "openness to experience" and "extraversion", educators should additionally find out ways to increase the "conscientiousness" and "agreeableness" traits of students. Furthermore, future research additionally should focus on surveys on finding out if the accomplished "openness to experience" and "extraversion" of final year students still continues during their professional life or are these findings just an "empty promise" to the employers.

It should be finally added that counseling programmes in Universities should be planned and organized by understanding the burnout levels of students which are affected by both the personality traits of students and education requirements of different years in different departments. Future work of this research will thus focus on civil engineering and computer engineering students in order to determine the effect of departmental differences on burnout levels of students and guide counseling programmes within the University accordingly.

\section{Acknowledgements}

This project is supported by Cukurova University Research Funding (MMF2011BAP25).

\section{REFERENCES}

Aghaee, N. G., \& Ören, T. (2004). Effects of cognitive complexity in agent stimulation. Summer Computer Stimulation Conference, 25-29 July 2004, San Rose, 15-19.

Bakker, A. B., Demerouti, E., \& Schaufeli, W. B. (2002). Validation of Maslach Burnout Inventory-General Survey: An internet study. Anxiety, Stress and Coping, 15, 245-260. doi:10.1080/1061580021000020716

Bakker, A. B., Van Der Zee, K. I., Lewig, K. A., \& Dollard, M. F. (2006). The relationship between the big five personality factors and burnout: A study among volunteer counselors, The Journal of Social Psychology, 146, 31-50. doi:10.3200/SOCP.146.1.31-50

Breso, E., Salanova, M., \& Schaufeli, W. B. (2007). In search of the "third dimension" of burnout: Efficacy or inefficacy? Applied Psychology: An International Review, 56, 460-478. doi:10.1111/i.1464-0597.2007.00290.x

Breso, E., Schaufeli, W. B., \& Salanova, M. (2011). Can a self-efficacy-based intervention decrease burnout, increase engagement, and enhance performance? A quasi-experimental study. Higher Education, 61, 339-355.

Bühler, K. E., \& Land, T. (2004). Burnout and personality in extreme nursing: An empirical study. Swiss Archives of Neurology and Psychiatry, 155, 35-42.

Chernyshenko, S. (2001). Applications of ideal point approaches to scale construction and scoring in personality measurement: The development of a six-faceted measure of conscientiousness. Ph.D. Dissertation, Urbana: Bemidji State University.

Cheung, F. M., van de Vijver, F. J. R., \& Leong, F. T. L. (2011). Toward a new approach to the study of personality in culture. American Psychologist, 66, 593-603. doi:10.1037/a0022389

Cohen, J., Cohen P., West, S. G., \& Aiken, L. S. (2002). Applied multiple regression/correlationanalysis for the behavioral sciences (3rd ed.). Hove: Psychology Press.

Cook, V. D. (2005). An investigation of the construct validity of the big five construct of emotional stability in relation to job performance, job satisfaction an career satisfaction. Ph.D. Dissertation, Knoxville: The University of Tennessee.

Costa, P. T., \& McCrae, R. R. (2000). Revised neo personality inventtory. Interpretive Report.

http://www.acer.edu.au/documents/sample_reports/neo-pir-sample.p df

Davies, M. (1998). Understanding marketing. Upper Saddle River, NJ: Prentice Hall.
Demirkan, S. (2006). Özel sektördeki yöneticilerin ve çalişanlarin bağlanma stilleri, kontrol odaği, iş doyumu ve beş faktör kişilik özelliklerinin araştirilması. Yayınlanmamış Yüksek Lisans Tezi, Ankara Üniversitesi.

Deniz, A. (2007). Kişilik özellikleri ile algilanan risk arasindaki ilişkilerin incelenmesi üzerine bir araştirma, Yüksek Lisans Tezi, Erzurum: Atatürk Üniversitesi.

Durbin, A. (1994). Appliying psychology: Individual and organizational effectiveness. Upper Saddle River, NJ: Prentice Hall.

Ehrler, J. D. (2005). An investigation into the relation between five factor model of personality and academic achievement in children. Ph.D. Dissertation, Atlanta: The College of Education Georgia State University.

Eren, E. (2000). Örgütsel davraniş ve yönetim psikolojisi. Beta Yayinevi, İstanbul.

Esteve, E. B. (2003). Well-being and performance in academic settings: The predicting role of self-efficacy. Ph.D. Thesis, Jaume University, Spain.

Eysenck, H. J., \& Wilson, G. (2000). Kișiliğinizi tanıyın. Remzi Kitabevi, İstanbul.

Friday, A. S. (2004). Criterion-related validity of big five adolescent personality traits. Ph.D. Dissertation, Knoxville: The University of Tennessee.

Gan, Y., \& Shang, J. (2007). Coping flexibility and locus of control as predictors of burnout among Chinese college students. Social Behavior and Personality, 35, 1087-1098. doi: $10.2224 / \mathrm{sbp} .2007 .35 .8 .1087$

Ghorpade, J., Lackritz, J., \& Singh, G. (2007). Burnout and personality: Evidence from academia. Journal of Career Assessment, 15, 240-250. doi: $10.1177 / 1069072706298156$

Goldberg, L. R. (1990). An alternative description of personality, the big five factor structure. Journal of Personality and Social Psychology, 59, 1216-1229. doi:10.1037/0022-3514.59.6.1216

Gökdaş, İ. (1996). Bilgisayar eğitimi ögretim teknolojisi. Ankara: Ankara Üniversitesi, Sosyal Bilimler Enstitüsü, Eğitim Programları ve Öğretimi Anabilim Dalı (Yayınlanmamıș Yüksek Lisans Tezi).

Güney, S. (2000). Davranış bilimleri. Nobel Yayın Dağıtım, Baskı, Ankara.

Hankin, B., Lakdawalla, Z., Carter, L., Abela, J., \& Adams, P. (2007). Are Neuroticism, cognitive vulnerabilities and self esteem overlapping or distinct risks for depression? Evidence from exploratory and confirmatory factor analyses. Journal of Social and Clinical Psychology, 26, 26s-63s.

Hu, Q., \& Schaufeli, W. (2009). The factorial validity of the Maslach Burnout Inventory-Student Survey in China. Psychological Reports, 105, 394-408. doi:10.2466/pr0.105.2.394-408

Jackson, L. T. B., \& Rothmann, S. (2005). An adapted model of burnout for educators in South African. South African Journal of Education, 25, 100-108.

Jia, Y. A., Rowlinson, S., Kvan, T., \& Lingard, H. C. (2009a). Burnout among Hong Kong Chinese architecture students: The paradoxical effect of Confucian Conformity values. Construction Management and Economics, 27, 287-298. doi:10.1080/01446190902736296

Jia, Y. A., Rowlinson, S., Kvan, T., Lingard, H., \& Yip, B. (2009b). Must burnout end up with dropout? The Built \& Human Environment Review, 2, 102-111.

John, O. P., \& Srivastava, S. (1999). The big-five trait taxonomy: History, measurement and theoretical perspectives (pp. 70-71). Oakland, CA: University of California.

Kalaycı, Ş. (2008). SPSS uygulamali çok değişkenli istatistik teknikleri. Asil Yayın, Ankara.

Kim, H. J., Shin, K. H., \& Swanger, N. (2009). Burnout and engagement: A comparative analysis using the big five personality dimensions. International Journal of Hospitality Management, 28, 96-104. doi:10.1016/j.ijhm.2008.06.001

Kokkinos, C. M. (2007). Job stressors, personality and burnout in primary school teachers. British Journal of Educational Psychology, 77 , 229-243. doi:10.1348/000709905X90344

Kokkonen, M., \& Pulkkinen, L. (2001). Examination of the paths between personality current mood, it's evaluation and emotion regulation. Journal of Personality, 15, 83s-104s. 
Kulik, L. (2006). Burnout among volunteers in the social services: The impact of gender and employment status. Journal of Community Psychology, 34, 541-561. doi:10.1002/jcop.20114

Lee, J., Puig, A., Kim, Y. B., Shin, H., Lee, J. H., \& Lee, S. M. (2010). Academic burnout profiles in Korean adolescents. Stress and Health, 26, 404-416. doi:10.1002/smi.1312

Lent, J. (2010). The impact of work setting, demographic factors and personality factors on burnout of professional counselors (pp. 102104). Ph.D. Thesis, Akron, OH: University of Akron.

Lindsfors, P. M., Nurmi, K. E., Meretoja, O. A., Luukkonen, R. A., Viljanen, A. M., Leino, T. J., \& Härmä, M. I. (2006). On-call stress among Finnish anaesthetists. Anaesthesia, 61, 856-866.

doi:10.1111/j.1365-2044.2006.04749.x

Lingard, H. C., Yip, B., Rowlinson, S., \& Kvan, T. (2007). The Experience of burnout among future construction professionals: A cross national study. Construction Management and Economics, 25, 345357. doi:10.1080/01446190600599145

Loveland, J. M. (2004). Cognitive ability, big five and narrow personality traits in the prediction of academic performance. Ph.D. Dissertation, Knoxville: The University of Tennessee.

Martinez, M. T. (2005). A correlational study between the mmpi-2, psy-5 and the 16pf global factors. Ph.D. Dissertation, Azusa, CA: Azusa Pacific University.

Maslach, C., Jackson, S. E., \& Leiter, M. P. (1996). Maslach burnout inventory manual (3rd ed.). Palo Alto, CA: Consulting Psychologists Press.

Maslach, C., \& Goldberg, J. (1998). Prevention of burnout: New perspectives. Applied \& Preventive Psychology, 7, 63s-74s. doi:10.1016/S0962-1849(98)80022-X

McCrae, R. R., Costa, P. T., \& Dye, D. A. (1991). Facet scales for agreeableness and conscientiousness; a revision of the personality inventory. Personality and Individual Differences, 12, 887s-898s. doi:10.1016/0191-8869(91)90177-D

McCrae, R. R., \& Terracciano, A. (2005). Personality profiles of cultures: Aggregate personality traits. Journal of Personality and Social Psychology, 89, 407-425. doi:10.1037/0022-3514.89.3.407

Morgan, C. T. (1999). Psikolojiye giriş. Eğitim Kitabevi, Bask1.

Morgan, B. (2008). The relationship between the big five personality traits and burnout in South African university students (pp. 108-117). Johannesburg: University of Johannesburg.

Myburgh, C., Poggenpoel, M., \& Plessis, D. D. (2011). Multivariate differential analyses of adolescents' experiences of aggression in families. South African Journal of Education, 31, 590-602.

Salanova, M., Schaufeli, W., Martinez, I., \& Breso, E. (2009). How obstacles and facilitators predict academic performance: The mediating role of study burnout and engagement. Anxiety, Stress \& Coping, 23, 53-70. doi:10.1080/10615800802609965

Perry, S. R. (2003). Big five personality traits and work drive as predictors of adolescent academic performance. Ph.D. Dissertation, Knoxville: The University of Tennessee.

Pienaar, J., \& Wyk, D. V. (2006). Teacher burnout: Construct equivalence and the role of union membership. South African Journal of Education, 26, 541-551.

Ried, L. D., Motycka, C., Mobley, C., \& Meldrum, M. (2006). Comparing self-reported burnout of pharmacy students on the founding campus with those at distance campuses. American Journal of Pharmaceutical Education, 70, 1-12. doi:10.5688/aj7005114
Schaufeli, W. B., \& Enzmann, D. (1998). The burnout companion to study and practice. A Critical Analysis, London: Taylor \& Francis.

Schaufeli, W. B., Martinez, I. B., Pinto, A. M., Salanova, M., \& Bakker, A. B. (2002). Burnout and engagement in university students: A cross national study. Journal of Cross-Cultural Psychology, 33, 464. doi:10.1177/0022022102033005003

Schmitt, D. P., Realo, A., Voracek, M., \& Allik, J. (2008). Why can't a man be more like a woman? Sex differences in big five personality traits across 55 cultures. Journal of Personality and Social Psychology, 94, 168-182. doi:10.1037/0022-3514.94.1.168

Somer, O., \& Goldberg, R. L. (1999). The structure of Turkish traitdescriptive adjectives. Journal of Personality and Social Psychology, 76, 431s-450s. doi:10.1037/0022-3514.76.3.431

Somer, O., Korkmaz, M., \& Tatar, A. (2002). Beş faktör kişilik envanterinin geliştirilmesi-i: Ölçek ve alt ölçeklerinin oluşturulmasi. Türk Psikoloji Dergisi, 17, 21s-33s.

Storm, K., \& Rothmann, S. (2003). The relationship between burnout, personality traits and coping strategies in a corporate pharmaceutical group. Journal of Industrial Psychology, 29, 35-42.

Swider, B. W., \& Zimmerman, R. D. (2010). Born to burnout: A metaanalytic path model of personality, job burnout and work outcomes. Journal of Vocational Behavior, 76, 487-506. doi:10.1016/j.jvb.2010.01.003

Şimşek, Ö. (2006). Insan dinamiği kişilik özelliklerinin incelenmesine yönelik ölçek geliştirme çalişması. Yayınlanmamış Yüksek Lisans Tezi, Sakarya: Sakarya Üniversitesi.

Tekin, H. (1996). Eğitimde ölçme ve değerlendirme. Ankara: Yarg1 Yayınlar1.

Tichon, M. A. (2005). Personnel selection in the transportation sector: An investigation of personality traits in relation to job performance of delivery drivers. Ph.D. Dissertation, Knoxville: The University of Tennessee.

Tomic, W., Tomic, D. M., \& Evers, W. J. G. (2004). A question of burnout among reformed church ministers in the Netherlands, mental health. Religion \& Culture, 7, 225-247. doi: $10.1080 / 13674670310001602472$

Turner, J. E. (2003). Proactive personality and big five as predictors of motivation to learn. Ph.D. Dissertation, Norfolk: Old Dominion University.

Weckwerth, A. C., \& Flynn, D. M. (2006). Effect of sex on perceived support and burnout in university students. College Student Journal, 40, 237-250

Yang, H. J. (2004). Factors affecting student burnout and academic achievement in multiple enrolment programs in Taiwan's technical-vocational colleges. International Journal of Educational Development, 24, 283-301. doi:10.1016/j.ijedudev.2003.12.001

Y1lmaz, A. (2007). İlkögretim müfettişlerinin mesleki görevlerini yerine getirme durumlari ile tükenmişlik düzeyleri arasindaki ilişki (pp. 89-90). Doktora Tezi, Bolu: Abant İzzet Baysal Üniversitesi.

Zhang, Y., Gan, Y., \& Cham, H. (2007). Perfectionism, academic burnout and engagement among chinese college students: A structural equation modeling analysis. Personality and Individual Differences, 43, 1529-1540. doi:10.1016/j.paid.2007.04.010

Zopiatis, A., Constanti, P., \& Pavlou, I. (2010). Investigating the association of burnout and personality traits of hotel managers. International CHRIE Conference, Refereed Track, Paper 11. 